\title{
Improved Learning Outcomes of Social Science Lessons Through Montase Technique
}

\section{Sri Wahyuni}

SD IT Nidaul Hikmah

yunisful@gmail.com

\section{Article History}

accepted $14 / 11 / 2020$

approved $21 / 11 / 2020$

published 26/11/2020

\begin{abstract}
The purpose of this research was to improve student learning outcomes in social science grade IV elementary shcool using montase technique. The reserach conducted was Classroom Action Research (PTK) with three cycles. The stages of each cycle are planning, implementing, observing, and reflecting. In teh first cycle the student who complete were 59,1\%, the second were $63,64 \%$, and the third were $81,82 \%$. These result indicate that montase technique can improve student learning outcomes, especially in social science lessons in grade IV Nidaul Hikmah Islamic Integrated Elementary School.
\end{abstract}

Keywords: learning outcomes, social science lessons, montase

\section{Abstrak}

Tujuan dari penelitian ini adalah untuk meningkatkan hasil belajar peserta didik pada mupel IPA di sekolah dasar kelas IV dengan penerapan teknik montase. Penelitian yang dilakukan adalah Penelitian Tindakan Kelas (PTK) sebanyak tiga siklus. Tahapan setiap siklusnya adalah perencanaan, pelaksanaan, observasi, dan refleksi. Pada siklus I peserta didik yang tuntas sebesar $59,1 \%$. Pada siklus II peserta didik yang tuntas sebesar $63,64 \%$. Pada siklus III peserta didik yang tuntas sebesar $81,82 \%$. Hasil ini menunjukkan bahwa teknik montase dapat meningkatkan hasil belajar peserta didik khususnya mupel IPS Kelas IV di SD IT Nidaul Hikmah.

Kata kunci: hasil belajar, IPS, montase

Social, Humanities, and Education Studies (SHEs): Conference Series https://jurnal.uns.ac.id/shes

p-ISSN 2620-9284

e-ISSN 2620-9292 


\section{PENDAHULUAN}

Ketika virus corona datang semua tatanan berubah begitupun terhadap dunia pendidikan. Pembelajaran tatap muka di sekolah dilarang diganti dengan pembelajaran dari rumah sesuai dengan Surat Edaran Nomor 4 Tahun 2020 Tentang Pelaksanaan Kebijakan Pada Masa Pandemi Belajar dari Rumah melalui pembelajaran daring/jarak jauh dilaksanakan untuk memberikan pengalaman belajar yang bermakna bagi peserta didik, tanpa terbebani tuntutan menuntaskan seluruh capaian kurikulum untuk kenaikan kelas maupun kelulusan. Masalah yang baru pun muncul, selain bagaimana melaksanakan pembelajaran jarak jauh tetapi juga bagimana cara guru tetap melakukan proses pembelajaran yang baik selama pandemi. Proses pembelajaran yang baik harus disesuaikan dengan karakteristik peserta didik agar peserta didik dapat menangkap materi yang diajarkan dengan baik. Pembelajaran yang dilakukan oleh guru juga harus kreatif dan tidak boleh monoton sehingga peserta didik tidak bosan. Penyampaian materi juga harus bervariasi agar peserta didik terdorong semangatnya sehingga aktif dan terus belajar. Guru tidak hanya berfokus pada penyampaian materinya tetapi juga harus memperhatikan perkembangan peserta didik yang terjadi di dalam proses pembelajaran.

Menurut Brunner dalam Sugandi (2007:36) ada empat hal pokok penting yang perlu diperhatikan yaitu peranan pengalaman struktur pengetahuan, kesiapan mempelajari sesuatu, intuisi dan cara membangkitkan motivasi belajar. Guru dituntut untuk bisa membawa peserta didik ke dalam dunia yang menyenangkan di dalam pembelajaran. Peserta didik yang merasa nyaman dan senang, maka akan berani untuk aktif dan akan mempunyai motivasi lebih untuk terus belajar. Peserta didik yang mempunyai motviasi lebih untuk belajar biasanya akan mendapatkan hasil belajar yang baik. Guru sebagai pemegang proses pembelajaran harus bisa menyajikan hal terbaik. Model pembelajaran yang digunakan haruslah sesuai dengan materi yang sedang diajarkan, karena tidak semua model pembelajaran dapat digunakan untuk semua materi. Pemilihan model pembelajaran akan mendukung hasil pembelajaran yang akan dicapai. Semua muatan pelajaran membutuhkan penerapan model pembelajaran.IImu Pengetahuan Sosial (IPS) merupakan salah satu mata pelajaran yang diberikan mulai SD/MI/SDLB sampai SMP/MTs/SMPLB. IPS mengkaji seperangkat peristiwa, fakta, konsep, dan generalisasi yang berkaitan dengan isu sosial. Pada jenjang SD/MI mata pelajaran IPS memuat materi geografi, sejarah, sosiologi dan ekonomi. Melalui mata pelajaran IPS, diarahkan untuk dapat menjadi warga negara Indonesia yang demokrasi dan bertanggungjawab, serta warga dunia yang cinta damai (KTSP Standar Isi 2006).

Selain itu, pembelajaran IPS yang berlangsung di SD merupakan pembelajaran yang mengenalkan siswa dengan konsep-konsep yang ada di lingkungan dan kehidupan masyarakat melalui cara yang mendorong siswa untuk berfikir logis dan kritis untuk menemukan permasalahan sosial yang terjadi serta menemukan solusi dalam permasalahan tersebut yang mendorong munculnya kesadaran dan komitmen terhadap nilai-nilai sosial dan kemanusiaan yang nantinya akan dijadikan bekal dalam berkomunikasi di dalam kehidupan bermasyarakat.

Meningkatnya hasil belajar merupakan salah satu indikator pencapaian tujuan pendidikan yang mana hal itu tidak terlepas dari motivasi peserta didik maupun kreativitas guru dalam menyajikan suatu materi pelajaran melalui berbagai media untuk dapat mencapai tujuan pengajaran secara maksimal. Dalam interaksi belajar mengajar, media pembelajaran di pandang sebagai salah satu unsur penting dalam rangka mencapai tujuan pengajaran. Dengan menggunakan Media Pembelajaran merupakan alat untuk mencapai tujuan pengajaran yang ingin dicapai sehingga semakin baik penggunaan media pembelajaran semakin berhasil pencapaian tujuan.

Menurut hasil observasi penulis, masih terdapat hasil belajar peserta didik yang sangat rendah pada materi IPS. Hal ini karena peserta didik sendiri yang bermalas- 
malasan karena kurang tertarik terhadap pengajaran yang disampaikan, siswa pasif karena pembelajaran hanya terkesan satu arah. Hal ini disebabkan guru hanya berceramah saja tanpa mengaktifkan siswa.

Penggunaan teknik penyampaian harus sesuai dengan materi yang disampaiakn, jika tidak sesuai maka tujuan pembelajaran yang diinginkan tidak akan tercapai. Hasil belajar IPS juga akan rendah karena peserta didik tidak memahami materi yang disampaikan. Kasus rendahnya pemahaman peserta didik mengenai materi IPS masih banyak terjadi di SD, seperti halnya di SD IT Nidaul Hikmah. Hasil belajar IPS pada peserta didik kelas IV masih rendah, hal ini terlihat dari hasil evaluasi dimana hanya terdapat 27,27\% peserta didik yang tuntas dengan Kriteria ketuntasan Minimum (KKM) sebesar 75 . Ketuntasan belajar klasikal belum tercapai, yaitu sebesar $75 \%$ peserta didik memperoleh nilai di atas KKM.

Menurut Hamalik (2004: 31) hasil belajar adalah pola-pola perbuatan, nilai-nilai, pengetahuan-pengetahuan, sikap-sikap, apresiasi, abilitas, dan keterampilan. Hasil belajar adalah kemampuan-kemampuan yang dimiliki siswa setelah menerima pengalaman belajarnya (Sudjana, 2002:22). Sedangkan menurut Horwart Kingsley dalam bukunya Sudjana membagi tiga macam hasil belajar mengajar: (1) Keterampilan dan kebiasaan, (2) Pengetahuan dan pengarahan, (3) Sikap dan cita-cita (Sudjana, 2002: 22). Hasil belajar yang dicapai siswa dipengaruhi oleh dua faktor yakni faktor dari dalam diri siswa dan faktor dari luar diri siswa (Sudjana, 2002:39). Dari pendapat ini faktor yang dimaksud adalah faktor dalam diri siswa, perubahan kemampuan yang dimilikinya seperti yang dikemukakan oleh Clark dalam Sudjana (2002: 21) menyatakan bahwa hasil belajar siswa di sekolah $70 \%$ dipengaruhi oleh kemampuan siswa dan 30\% dipengaruhi oleh lingkungan. Demikian juga faktor dari luar diri siswa yakni lingkungan yang paling dominan berupa kualitas pembelajaran (Sudjana, 2002:39).

Menurut Hamid Hasan, dkk (2009:1) sebaiknya pembelajaran IPS mampu mempersiapkan, membina, dan membentuk kemampuan peserta didik yang menguasai pengetahuan, sikap, nilai, dan kecakapan dasar yang diperlukan bagi kehidupan di masyarakat. Kualitas dan keberhasilan pembelajaran sangat dipengaruhi oleh kemampuan dan ketepatan guru dalam memilih dan menggunakan metode pembelajaran. Montase merupakan salah satu teknik yang menjadi rujukan dalam penyampaian materi IPS karena tekniknya mengkombinasikan gambar-gambar jadi dari berbagai sumber menjadi susunan karya seni baru. Sumber yang dimaksud dapat digunakan koran, majalah bekas, buku yang tidak digunakan, brosur atau lainnya. Menurut IImu (Soemantri, 2004) IImu Pengetahuan Sosial diajarkan di sekolah dasar, dimaksudkan agar siswa menjadi manusia dan warga negara yang baik, seperti yang diharapkan oleh dirinya, orang tua, masyarakat, dan agama. Dengan demikian, pembelajaran IPS di sekolah dasar pada dasarnya dimaksudkan untuk pengembangan pengetahuan, sikap, nilai-moral, dan keterampilan siswa agar menjadi manusia dan warga negara yang baik, seperti yang diharapkan oleh dirinya, orang tua, masyarakat, dan agama.

\section{METODE}

Penelitian ini adalah penelitian tindakan kelas (Classroom Action Research) dengan menerapkan teknik montase. Menurut Kurt Lewin dan Kunandar (2011:42) penelitian tindakan kelas ini terdiri dari empat tahapan dasar yaitu perencanaan (planning), pelaksanaan (acting), pengamatan (observing) dan refleksi (reflecting). Teknik analisis data yang dipakai adalah deskriptif komparatif dengan presentase. Hasil dari analisis tersebut dibandingkan dan dideskriptifkan dalam berbagai tindakan lanjutan pada tiap siklusnya. Penelitian ini dilaksanakan pada peserta didik kelas IV SD IT Nidaul Hikmah Tahun Pelajaran 2020/ 2021 selama tiga siklus secara luring menggunakan teknik montase. Siklus I dilaksanakan pada tanggal 2 November 2020. Siklus II dilaksanakan pada tanggal 9 November 2020. Siklus III dilaksanakan pada 
tanggal 20 November 2020. Teknik pengumpulan data yang dilakukan dengan observasi dan tes. Observasi meliputi keterlaksanaan teknik montase. Untuk hasil belajar menggunakan lembar evaluasi.

\section{HASIL DAN PEMBAHASAN}

Pada siklus I membahas tentang Berbagai Pekerjaan. Proyek yang dibuat peserta adalah memasangkan gambar pekerjaan sesuai wilayahnya secara berkelompok. Berikut adalah hasil belajar peserta didik pada siklus I yang bisa dilihat pada tabel berikut:

Tabel 1. Rata-rata Persentase hasil belajar Pra Siklus dan Siklus I

\begin{tabular}{cc} 
Tabel 1. Rata-rata Persentase hasil belajar Pra Siklus & dan Siklus \\
\hline Rata-rata Persentase Hasil & Belajar \\
\hline Pra Siklus & Siklus I \\
$27,27 \%$ & $40,90 \%$ \\
Peningkatan $=40,90 \%-27,27 \%=13,63 \%$ \\
\hline
\end{tabular}

Berdasarkan data dalam tabel 1 rata-rata persentase hasil belajar siswa pada pra siklus sebesar 27, 27\% meningkat pada siklus I menjadi 40, 90\% sehingga mengalami peningkatan sebesar 13,63\%. Agar lebih jelas dapat dibaca pada diagram batang berikut:

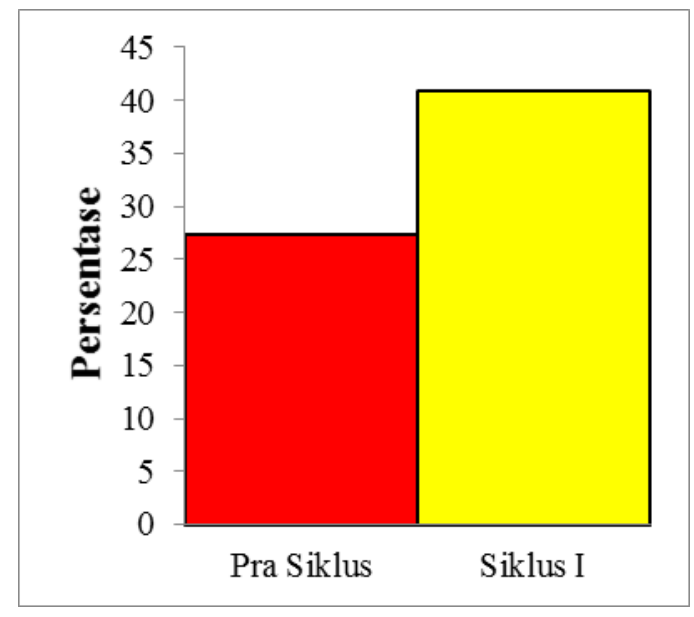

\section{Gambar 4.1. Diagram hasil belajar siswa siklus I}

Berdasarkan refleksi pada siklus I maka diputuskan untuk melanjutkan ke siklus II dikarenakan belum mencapai ketuntasan klasikal yang diharapkan. Siklus II masih membahas berbagai Pekerjaan dengan membuat montase secara individu. Berikut ini adalah hasil belajar peserta didik pada siklus II yang bisa dilihat pada tabel berikut:

Tabel 2. Rata-rata Persentase hasil belajar Siklus I dan Siklus II

$\begin{array}{cc}\text { Rata-rata Persentase Hasil Belajar } \\ \text { Siklus II } \\ \text { Siklus I } & 63,64 \% \\ 40,90 \% & =22,74 \% \\ \text { Peningkatan }=63,64 \%-40,90 \%=2\end{array}$

Berdasarkan data dalam tabel 2 rata-rata persentase hasil belajar siswa pada siklus I sebesar 40, $90 \%$ meningkat pada siklus II menjadi 63, $64 \%$ sehingga mengalami peningkatan sebesar $22,74 \%$. Agar lebih jelas dapat dibaca pada diagram batang berikut: 


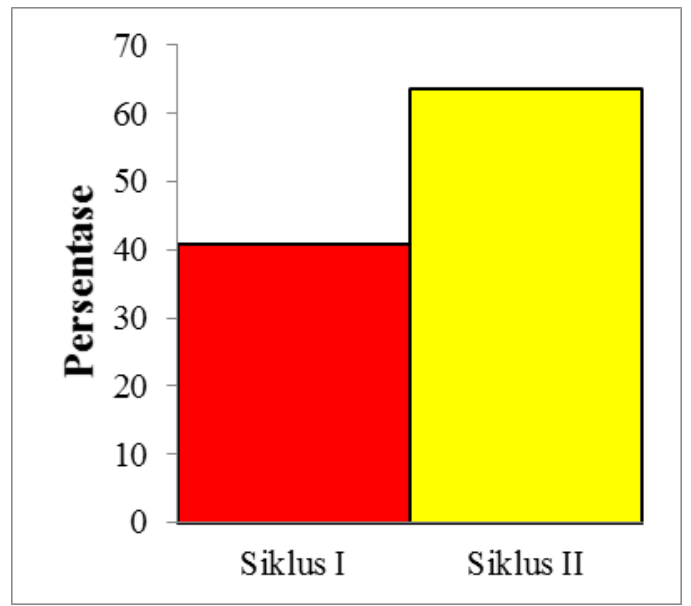

\section{Gambar 4.2. Diagram hasil belajar siswa siklus II}

Berdasarkan refleksi pada siklus II maka diputuskan untuk melanjutkan ke siklus III dikarenakan belum mencapai ketuntasan klasikal yang diharapkan. Siklus III masih membahas berbagai Pekerjaan dengan membuat montase secara individu dengan bentuk soal evaluasi isian singkat. Berikut ini adalah hasil belajar peserta didik pada siklus III yang bisa dilihat pada tabel berikut:

\section{Tabel 3. Rata-rata Persentase hasil belajar Siklus II dan Siklus III}

$\begin{array}{cc}\text { Rata-rata Persentase Hasil Belajar } \\ \text { Siklus III } \\ \text { Siklus II } & 81,82 \% \\ 63,64 \% & 18,18 \% \\ \text { Peningkatan }=81,82 \%-63,64 \%=18\end{array}$

Berdasarkan data dalam tabel 2 rata-rata persentase hasil belajar siswa pada siklus II sebesar 63, $64 \%$ meningkat pada siklus III menjadi $81,82 \%$ sehingga mengalami peningkatan sebesar $18,18 \%$. Agar lebih jelas dapat dibaca pada diagram batang berikut:

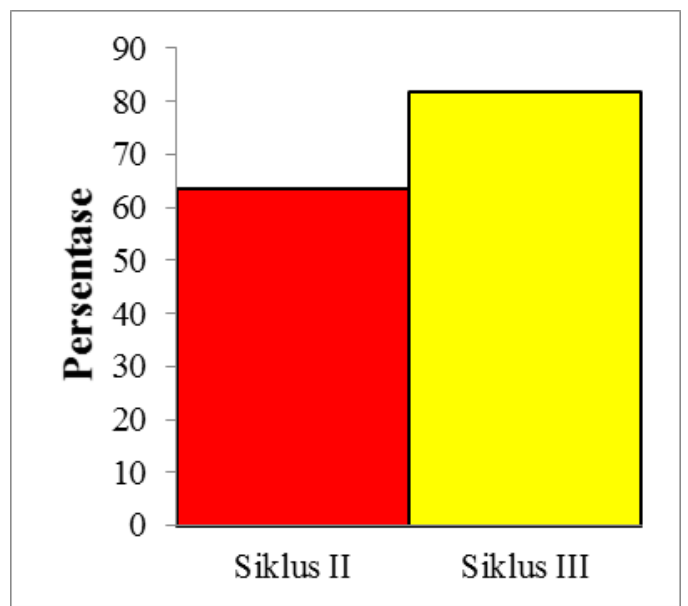

\section{Gambar 4.3. Diagram hasil belajar siswa siklus III}

Dari tiga siklus yang sudah dilaksanakan dapat dipastikan bahwa penerapan teknik montase dapat meningkatkan hasil belajar peserta didik pada mupel IPS Kelas IV di SD IT Nidaul Hikmah. Hal ini sesuai dengan konsep atau teori yang diungkap oleh Nanang Hanafiah dan Cucu Suhana (2009:30) bahwa langkah penerapan model pembelajaran ini merupakan model pembelajaran inovatif yang melibatkan kerja proyek dimana peserta didik bekerja secara mandiri dalam 
mengkonstruksi pembelajarannya dan mengkulminasikannya dalam produk nyata. Hasil penelitian ini juga sesuai dengan penelitian sebelumnya yang dilakukan oleh Taznidaturrohmah, dkk (2020) yang membuktikan bahwa teknik montase dapat meningkatkan hasil belajar dan kreativitas peserta didik.

\section{SIMPULAN}

Penerapan teknik montase dapat meningkatkan hasil belajar peserta didik Kelas IV pada mupel IPS materi berbagai pekerjaan. Peningkatan yang terjadi karena adanya kesan pembelajaran yang mendalam dari peserta didik tehadap materi yang diajarkan melalui setiap proyek yang dibuat. Berdasarkan penelitian yang telah dilaksanakan salah satu teknik yang harus dikuasai guru adalah teknik montase karena model ini sangat cocok digunakan dalam keadaan pandemi seperti ini, apalagi dalam kondisi belajar dari rumah. Guru bisa memantau proses selama proyek dilaksanakan dengan bekerja sama dengan orang tua.

\section{DAFTAR PUSTAKA}

(2006). Kurikulum Standar Kompetensi. Jakarta: Depdiknas

Aqib, Zainal, dkk. (2011). Penelitian Tindakan Kelas untuk Guru SD, SLB, dan TK. Bandung: Yrama Widya.

Gunawan, Rudy. 2011. Tujuan Pembelajaran IPS Sekolah Dasar. http://www.rudygunawan.blogspot.com. (29 Oktober 2020).

Hasan, Hamid. 2009. Pembelajaran Pendidikan IPS di Sekolah Dasar. http://www.pembelajaran.wordpress.com/. (29 Oktober 2020).

Hopkins, David. 1993. A Teacher's Guide to Classroom Research. Philadelphia: Open University Press.

Kagan. 2004. Pembelajaran Pendidikan IPS di Sekolah Dasar. http://www.pembelajaran.wordpress.com/. (29 Oktober 2020).

Kunandar. 2008. Langkah Mudah Penelitian Tindakan Kelas. Jakarta: Rajawali

Mulyatiningsih, Endang. 2011. Metode Penelitian Terapan Bidang Pendidikan. Bandung: Alfabeta.

Padmono, Y. 2010. Kekurangan dan kelebihan, Manfaat Penerapan PTK. Online: edukasi.kompasiana.com.

Pers Arikunto, Suharsimi, dkk. 2006. Penelitian Tindakan Kelas. Jakarta: PT Bumi Aksara

Sudjana, N. (2002). Tuntutan Penyusunan Karya IImiah, Makalah-SkripsiTesisDisertasi. Bandung: Sinar Baru

Sudjana, N. 2009. Penilaian Hasil Proses Belajar Mengajar (Cetakan Ketigabelas). Bandung: PT Remaja Rosdakarya.

Taznidaturrohmah, dkk (2020). Upaya meningkatkan kemampuan motorik halus melalui kegiatan montase pada anak kelompok B di TK Dharma Wanita Dinoyo 01 Mojokerto. Jurnal Pendidikan Anak. Volume 9 (1):21 